\title{
Firms' Financing Choices and Profitability in the For-Profit Education Industry: An Empirical Survey of Education Companies Listed on the NYSE and NASDAQ Stock Markets
}

\author{
Andrea Quintiliani ${ }^{1}$ \\ ${ }^{1}$ Department of Law and Economic Sciences, Pegaso Telematic University, Naples, Italy \\ Correspondence: Andrea Quintiliani, Department of Law and Economic Sciences, Pegaso Telematic University, \\ Naples, NA, Directional Center of Naples, Pegaso Tower F2, Italy. E-mail: andrea.quintiliani@unipegaso.it
}

Received: March 13, 2020

Accepted: April 6, 2020

Online Published: April 7, 2020

doi:10.5430/afr.v9n2p46

URL: https://doi.org/10.5430/afr.v9n2p46

\begin{abstract}
This study seeks to understand financing choices and its relationships with profitability of for-profit education companies listed on NASDAQ and NYSE. This study tests the hypothesis that knowledge-based firms with higher assets intangibility used less debt in their capital structures than capital-intensive firms with higher assets tangibility. Capital structure theory is a useful framework to explain research findings. Tests were conducted on a sample consisting of education companies and capital-intensive firms listed on NASDAQ and NYSE during the period 2000-2018. Data collected by Zacks Premium database were submitted to regression analysis. Findings suggest that capital-intensive firms have higher debt ratios than education companies. Also, this study finds existence of a strong inverse relationship between profitability and the amount of debt in the capital structure of capital-intensive firms while no such relationship was found between these two variables for the education companies. This study's findings could provide valuable information to policymakers and investors to identify suitable financing policies in the for-profit education industry. Findings can also be useful to stimulate debate on the role of equity financing to supporting growth policies of for-profit education industry. This study attempts to fill the absence of empirical studies on financial policies of for-profit education firms.

Contribution/ Originality: The main contribution of this study is that it will increase knowledge about funding able to sustain for-profit education firm's growth. Furthermore, this study tries to fill the lack of studies who investigate explicitly (empirically or theoretically) funding policies of for-profit education firms.
\end{abstract}

Keywords: capital structure, for-profit education company, financing policies, knowledge-based firm, intangible asset

\section{Introduction}

In this study funding choices refers decisions made by CFO about capital structure. Funding choices remains a controversial issue. Finance theory formally studied financing choices of firms following the investigation logic of the "capital structure", a term used to identify the combination existing between debt and equity in a firm.

One of the most controversial questions in finance is whether there is an optimal capital structure puzzle, or better yet a specific relationship between debt and equity that maximizes the value of the firm. The pioneering study of Modigliani and Miller (1958) gave an answer to these questions highlighting paradox of "capital structure irrelevance". Since then, corporate financial literature has seen a succession of numerous theoretical approaches, including: the trade-off theory (Kraus and Litzenberger, 1973; Jensen, 1986), the agency theory (Jensen and Meckling, 1976), the signaling theory (Ross, 1977), the pecking order theory (Myers, 1984; Myers and Majluf, 1984), and the market timing theory (Lucas and Mcdonald, 1990; Bakar and Wurgler, 2002). Also interesting is there was a recent study by Kopecky et al. (2018) which highlights how the advent of well-capitalized takeover companies, including private equity firms and sovereign funds, is reason to reinterpret the concept of firm's target capital structure.

Many empirical studies have tried to find correlations and sign (positive or negative) between factors specific to a firm and leverage. For example, a growing body of literature suggests following relationships by: Income variability and Leverage - Negative (Harris and Raviv, 1991; Frank and Goyal, 2009); Firm's growth opportunity and Leverage 
- Negative (Titman and Wessels, 1988; Rajan and Zingales, 1995); Tangibility and Leverage - Positive (Scott, 1977; Myers and Majluf, 1984; Titman and Wessels, 1988; Frank and Goyal, 2009); Intangibility and Leverage - Negative (Singh and Faircloth, 2005; Aghion et al., 2004); Firm size and Leverage - Positive (Jensen and Meckling, 1976; Titman and Wessels, 1988; Rajan and Zingales, 1995); Profitability and Leverage - Positive (Myers and Majluf, 1984; Rajan and Zingales, 1995; Banerjee et al., 2004); Non-debt tax shield and Leverage - Negative (DeAngelo and Masulis, 1980); Firm's uniqueness and Debt financing - Negative (Titman and Wessels, 1988); Firm leverage and Industry median leverage - Negative (Frank and Goyal, 2009).

This work investigates the relative importance of four factors upon the capital structure decisions: firm size, risk, collateral availability, and growth opportunities.

Studies on capital structure covered many industries, including knowledge-based industries. Despite the existence of many empirical studies investigating the impact of firms' characteristics on financial policies, quite surprisingly there is no research explicitly investigating (empirically or theoretically) funding policies of for-profit education firms, a gap which this work intends to fill. In addition to filling knowledge gap, this study focuses on the for-profit education industry as it has attracted many investments in recent years.

Some authors (Aghion et al., 2004; Frank and Goyal, 2009) point out that equity funds represent the first choice of funding for knowledge-based enterprise. Other authors (Shyam-Sunder and Myers, 1994; Ang et al., 2000; Bah and Dumontier, 2001) add that these companies have characteristics that limit their chances of obtaining financing from external sources (banks): they have poor collateral, their assets are mostly intangibles and the value of their resources is difficult to calculate. For these reasons, entrepreneurs in knowledge-intensive industries tend to rely heavily on equity.

In recent years we have seen for-profit education companies that have turned to the private equity market. The reason for so much private equity interest in the education industry is that it is often non-cyclical and with high growth opportunities. Many private equity firms have made investments in this industry, among them: Education Growth Partners, Epic Partners, Renovus Capital, Sterling Partners, CVC Capital Partners, and Prospect Partners.

Among the main private equity operations in the education industry, it is worth mentioning that of CVC Capital Partners which in the august 2019 through its CVC VII fund has acquired 50\% of the share of Multiversity, the owner of Italy's largest online university "Pegaso", as well as Mercatorum University. In this operation, multiples have been able to intercept the wealth of knowledge and high endowment of intangible resources of the target Pegaso.

According to Leventhal and Tang (2013), advances in technology, and e-learning platforms, have stimulated the growth of education companies and have spurred the interest of private equity investors.

This study does not consider public education companies whose funding choices are heavily influenced by national or subnational government parameters.

This work focuses on private education sector which has attracted interest of many private equity firms and has seen many education companies listed on stock markets.

On the equity side, many for-profit education companies have started looking at the stock market. This choice is justified by the need to finance more investments in technology. Indeed, as an article on Nasdaq.com (2018) make clear: «Education companies are increasingly switching to online education programs, using more of technology in education, increasing investment in overall education, regularly introducing programs and specializations to boost student outcome».

The aim of this work is twofold. Firstly, to analyse financing choices by education companies listed on NASDAQ and NYSE from 2000 to 2018. Secondly, to test relationship between amount of debt in the capital structure and profitability. To this end, educational companies which are known to have a high endowment of intangible capital (R\&D, firm-specific human, technology, branding, patent, trademark, copyright etc.) were compared with the companies capital-intensive who possess a high physiological percentage of material assets. To reveal capital structure, it will be used financial leverage ratio (debt-to-assets).

Therefore, within the theoretical frameworks of capital structure theory, this study tries to test the following research hypotheses:

H1. For-profit education firms are characterized by the greater use of equity in their capital structures than capital-intensive firms.

H2. There is an inverse relationship between profitability and the amount of debt in the for-profit education firm's 


\section{capital structure.}

This study is aware of the evident endogeneity problems that can compromise statistical relevance of empirical results. Empirical corporate finance is commonly plagued by the difficulty of finding good instrumental variables as well as by endogeneity and causation problems. In literature we find studies that have successfully used instrumental variables. For example, the studies by Bennedsen et al. (2007), Laeven and Levine's (2009), and Giroud et al. (2012). Methods to deal with the endogeneity problem are well indicated by Li (2016). Li's study makes it clear that econometric remedies are useful to mitigate the endogeneity bias, but the effects vary considerably. Among all the remedies highlighted in the literature, GMM method, instrumental variables, fixed effects models, lagged dependent variables, and control variables, and combined methods are considered as appropriate ( $\mathrm{Li}, 2016)$. In this study, capital structure explanatory variables were chosen also in relation to the findings of previous studies that tested the endogeneity of the explanatory variables using GMM estimator (Arellano and Bover, 1995; Blundell and Bond, 1998).

This work proceeds as follows: Section 2 offers a bibliographical framework. Section 3 explains data and sample selection. Section 4 summarizes the research results. Section 5 is devoted to drawing conclusions.

\section{Literature Review}

There is a wide consensus that firms' knowledge-intensive are negatively associated with leverage. Before clarifying this aspect, it is useful to distinguish companies in relation to their capital endowment. In literature there is a clear distinction between knowledge-intensive companies and capital-intensive companies.

According to the OECD (1999), the term "knowledge-based industries" refers to industries mainly driven by the relevance of intangible assets and/or more labor-intensive. This definition includes the following services activities: communications, finance, insurance, real estate, business services, community, social and personal services (including, among others, health and education).

While knowledge-intensive companies have a relatively high proportion of labour and intangible assets, capital-intensive companies are characterized by strong endowment of tangible assets. Intangible intensity is defined as the ratio between intangible assets and total assets. The degree of labor intensity is typically measured in proportion to the amount of capital required to produce the goods or services.

Therefore, this study distinguishes labour and intangible intensive companies (knowledge companies - KNWL) from capital-intensive companies (CI) that own a relatively high proportion of hard assets.

In this study, the selection of a sample of firms operating in the education industry is not accidental. Indeed, education sector is highly knowledge-based, and its firms are labor and intangible-intensity. Therefore, KNWL sample is strictly representative of the knowledge-based industries and able to test research hypotheses of this study.

The companies operating in the knowledge sector are labor-intensive. Compared to other industries, human capital represents a real intellectual capital generating intangible assets. Several authors have indeed suggested that the quality of the human resources employed by firms is a basic condition both for generating intangible assets and for their economic exploitation (Abramovitz and David, 2000; Galor and Moav, 2004).

As many studies have shown (Singh and Faircloth, 2005; Aghion et al., 2004), labor and intangible-intensity are negatively associated with leverage. The main reason for this relationship is that intangible and human assets cannot be used as collateral (Titman and Wessels, 1988; Harris and Raviv 1991; O’Brien, 2003; Frank and Goyal, 2009). Indeed, collateralizing intangible assets is challenging. Compared to tangible asset, intangible is abstract, hard to define or measure. Moreover, its repossessing in case of default of the owner imply evident agency problems (Rampini and Viswanathan, 2013). As Canarella and Miller's (2019) study clarify, features of intangible assets and the risk profile intangible investments encourage equity financing and discourage leverage.

Many scholars have tried to investigate financial policies of firms operating in knowledge-based industries. Canarella and Miller's (2019) study show that U.S. ICT firms exhibit significant lower debt and dividend payment levels than non-R\&D firms. Brown et al.'s (2009) study show that capital structure of high-tech firms is strongly correlated to firm's investment prospects which in turn rely on other factors such as agency, information asymmetry, asset substitution and uniqueness etc. This is in line with previous Carpenter and Petersen' study (2002).

The problem of explaining firms' capital structure is intensely debated in corporate finance. Main literature highlights five problems or perils that justify capital structure choice: the underinvestment problem, the uncertainty/asset substitution problem, the problem of free cash flow, asset specificity, and information asymmetry.

The underinvestment problem: This underinvestment problem suggests that knowledge-intensive firms favor equity 
financing to reduce the cost requirements of debt holders (Myers, 1977).

The uncertainty/asset substitution problem: According to the asset substitution hypothesis intangible-intensive companies are more inclined to use equity financing than debt (Bah and Dumontier, 2001; Parthiban et al., 2008).

The problem of free cash flow: Many authors (Jensen, 1986; Titman and Wessels, 1988; MacKie-Mason, 1990) believe that at greater business profitability follow greater use of debt. This relationship is justified by the need to control the agency costs associated with free cash flow. This aspect was first explored by Jensen (1986). Jensen's theory implies a direct relationship, profitability and the amount of debt in a firm's capital structure. This theory is opposed by Myers and Majluf's theory (1984) which highlights how asymmetric information in the capital markets determines an inverse relationship between profitability and the amount of debt in the firm's capital structure.

Asset specificity: Intangible investments such as $\mathrm{R} \& \mathrm{D}$, innovation and technology development add more knowledge-based intangible and specific assets to firm's total assets. According to the asset specificity problem, it states that firms with low level of specific assets should be more leveraged given that these assets can be used as collateral. Further, equity is more preferred when firms have more specific assets, i.e. involve more in R\&D, innovation activities, as debt will increase the transaction costs significantly (Harris and Raviv, 1991; Bah and Dumontier, 2001; Benmelech, 2009; Hall and Lerner, 2010; Qiu and La, 2010; Wang and Tornhill, 2010).

Information asymmetry: The information asymmetry phenomenon is more significant for labour and intangible-intensive firms. Many authors (Aghion et al., 2004; Hogan and Hutson, 2004) discuss reasons for this relationship. The asymmetric information approach assumes that managers have superior information about future returns and growth opportunities of the firm. One can anticipate that the level of insiders" "superior information" is higher in intangible asset intensive firms. Therefore, information asymmetries generate adverse selection and moral hazard problems. The widespread skills within private equity markets assists in overcoming information asymmetries. This encourages knowledge firms to address private equity market rather than lending market (Bradley et al., 1984; Robb and Robinson, 2014).

Starting from five key points listed above, this study attempts to verify if capital structure is different for KNWL and CI firms listed on the Nyse and Nasdaq stock markets. Additionally, this study test if there is an inverse relationship between profitability and the amount of debt in the for-profit education firm's capital structure. Therefore, the present work contributes to the capital structure literature through bringing evidence regarding financial policies of for-profit education firms.

\section{Data and sample Selection}

Based sample of this work is all firms operating in the education industry and in sectors that are capital intensive listed on the NYSE and NASDAQ stock markets that are reported on Zacks Premium database (10-31-19 version).

Companies operating in the utilities and financial services industries were eliminated from the sample. This choice is justified because of heavy regulation that affects these industries and that can make the research findings questionable.

Outliers were also eliminated from the base sample: education firms (capital-intensive firms) with total intangibles (total tangibles) on total assets of less than $50 \%$, and with cost of labor on the amount of capital required to produce the goods or services of less (of more) than 50\%. This skimming allows to select a sample more representative.

This resulted in a final sample of 15 education firms - KNWL (see table 1) and 51 capital-intensive firms - CI. The study sample of capital-intensive firms (CI) listed on the NYSE and NASDAQ stock markets consist of 25 companies operating in the oil and gas industry, and 26 operating in the steel industry.

Data for each sample company for the sample years 2000, 2004, 2009, 2014, and 2018 was obtained from Zacks Premium. Some companies did not have data for every sample year. The studies highlighted so far seem to relate the amount of debt in a firm's capital structure by several factors including primarily firm size, risk, collateral availability, and growth opportunities. These factors have also been identified in the studies by Rozeff (1982), Friend and Lang (1988), Titman and Wessels (1988), Harris and Raviv (1991), Jensen et al. (1992), Guedes and Opler (1996), Berger et al. (1997), Kim et al. (1998), Opler et al. (1999), and Baker et al. (2007).

As Dang et al.'s (2018) study suggests, different size proxies capture different aspects of firm size, and therefore their choice needs both theoretical and empirical justification. Corporate sized proxies of this study (assets, sales, and the market value of common stock) have been selected because they are commonly used in empirical corporate finance research that explores capital structure of knowledge-based enterprises (Shyam-Sunder and Myers, 1994; Ang et al., 2000; Bah and Dumontier, 2001; Aghion et al., 2004; Frank and Goyal, 2009). Their selection is 
therefore coherent with Dang et al.'s tips.

As mentioned above, company size proxies used in this study are assets (Assets), sales (Sales), and the market value of common stock (MVCS). Common stock is the amount that all common shareholders have invested in a company. The KNWL firm's assets are primarily intangible (on total assets $>50 \%$ ) while CI firm's assets are mainly tangible (on total assets > 50\%). Furthermore, KNWL firms have significant labor costs (on the amount of capital required to produce the goods or services $>50 \%$ ) compared to CI firms (on the amount of capital required to produce the goods or services $<50 \%$ ). NPP\&E ratio can be used to measure the level of tangibility (Titman and Wessels, 1988), and in this study it is used as a proxy for measuring the level of collateral availability. NPP\&E ratio compares company's property, plant and equipment to the total assets. Property, plant, and equipment is the value of all tangible assets, i.e. buildings, land, furniture, and other hard capital that a business has purchased to run its business. The term "Net" means that it is "Net" of accumulated depreciation expenses.

Table 1. Sample of education companies (KNWL) listed on the NYSE and NASDAQ stock markets

\begin{tabular}{|c|c|c|c|c|}
\hline Company Name & Core business & State & Symbol & $\begin{array}{c}\text { Stock } \\
\text { Market }\end{array}$ \\
\hline Afya Limited & Medical education & Brazil & AFYA & NASDAQ \\
\hline $\begin{array}{l}\text { Bright Horizons Family Solutions } \\
\text { Inc. }\end{array}$ & Provider of education and care solutions & USA & BFAM & NYSE \\
\hline $\begin{array}{l}\text { Bright Scholar Education Holdings } \\
\text { Ltd. }\end{array}$ & Education service & China & BEDU & NYSE \\
\hline Career Education Corporation & Postsecondary higher education provider & USA & PRDO & NASDAQ \\
\hline GP Strategies Corporation & Sales and technical training provider & USA & GPX & NYSE \\
\hline Grand Canyon Education Inc. & Educational learning solutions provider & USA & LOPE & NASDAQ \\
\hline K12 Inc. & Online schooling and curricula provider & USA & LRN & NYSE \\
\hline Laureate Education Inc. & $\begin{array}{l}\text { Provider of educational services for students } \\
\text { in primary and secondary education }\end{array}$ & USA & LAUR & NASDAQ \\
\hline $\begin{array}{c}\text { Lincoln Educational Services } \\
\text { Corporation }\end{array}$ & Provider of post-secondary education & USA & LINC & NASDAQ \\
\hline $\begin{array}{l}\text { New Oriental Education \& } \\
\text { Technology Group Inc. }\end{array}$ & Provider of private educational services & China & EDU & NYSE \\
\hline $\begin{array}{l}\text { OneSmart International Education } \\
\text { Group Limited }\end{array}$ & Provider of private educational services & China & ONE & NYSE \\
\hline $\begin{array}{l}\text { RISE Education Cayman Ltd. } \\
\text { American Depositary Shares }\end{array}$ & English teaching and tutoring services & China & REDU & NASDAQ \\
\hline RYB Education Inc. Sponsored ADR & Early childhood education & China & RYB & NYSE \\
\hline TAL Education Group & Provider of private educational services & China & TAL & NYSE \\
\hline Universal Technical Institute Inc. & Technical colleges & USA & UTI & NYSE \\
\hline
\end{tabular}


Growth indicators applied in this study are market to book value of common stock (MVCS/BVCS) and Tobin's q. Tobin's q index, according to the study by Chung and Pruitt (1994), is calculated as the sum of the book values of debt and preferred stock plus the market value of common stock divided by the sum of the book values of debt, preferred, and common stock.

This empirical analysis should indicate if education firms are characterized by the greater use of equity in their capital structures than capital-intensive firms (H1). Also, it should indicate if there is an inverse relationship between profitability and the amount of debt in the education firm's capital structure $(\mathrm{H} 2)$.

Profitability per sample year is measured by following ratios: ROA, ROE, and free cash flow ratio (FCF/Assets). Business risk is calculated in the period of 5 years from sample year ( $t$ to year $t-4$ ). In this study corporate risk is measured by standard deviation of ROA (Std. ROA).

\section{Empirical Results}

The mean values of selected variables for the KNWL sample firms for each of the sample years are presented in Table 2.

Table 2. Summary statistics for selected variables for the KNWL firms

\begin{tabular}{|c|c|c|c|c|c|}
\hline & 2000 & 2004 & 2009 & 2014 & 2018 \\
\hline \multicolumn{6}{|c|}{ Panel A: Firm Size } \\
\hline Assets $(\$ M)$ & 244 & 491 & 485 & 466 & 607 \\
\hline Assets (Std.) & .1002 & .0202 & .0200 & .0018 & .0031 \\
\hline Sales $(\$ M)$ & 529 & 673 & 638 & 516 & 593 \\
\hline Sales (Std.) & .0102 & .0105 & .0103 & .0009 & .0104 \\
\hline $\operatorname{MVCS}(\$ M)$ & 80 & 281 & 379 & 1664 & 1079 \\
\hline $\operatorname{MVCS}($ Std. $)$ & .0041 & .0094 & .0103 & .0162 & .0141 \\
\hline \multicolumn{6}{|c|}{ Panel B: Capital Structure } \\
\hline Debt $(\$ M)$ & 108 & 204 & 192 & 133 & 143 \\
\hline Debt (Std.) & .0061 & .0121 & .0043 & .0024 & .0033 \\
\hline Debt/Assets & .200 & .205 & .158 & .157 & .145 \\
\hline Debt/Assets (Std.) & .0061 & .0071 & .0021 & .0027 & .0014 \\
\hline Debt/T. Cap. & .261 & .268 & .240 & .199 & .171 \\
\hline Debt/T. Cap. (Std.) & .0042 & .0052 & .0042 & .0031 & .0028 \\
\hline \multicolumn{6}{|c|}{ Panel C: Profitability, Growth, etc. } \\
\hline ROA & .014 & .021 & .018 & -.006 & -.022 \\
\hline$R O A(S t d)$. & .0021 & .0034 & .0020 & .0001 & 0.002 \\
\hline ROE & .037 & .040 & .044 & -.001 & -.029 \\
\hline$R O E(S t d)$. & .0012 & .0015 & .0045 & .0004 & .0070 \\
\hline FCF/Assets & .101 & .100 & .088 & .072 & .031 \\
\hline FCF/Assets (Std.) & .0041 & .0133 & .0024 & .0015 & .0011 \\
\hline MVCS/BVCS & 2.69 & 2.51 & 2.64 & 4.98 & 3.12 \\
\hline$M V C S / B V C S(S t d)$. & .1655 & .1499 & .1201 & .1009 & .1401 \\
\hline Tobin's q & 2.29 & 2.11 & 2.33 & 4.98 & 3.01 \\
\hline Tobin's $q$ (Std.) & .1522 & .1322 & .1104 & .1102 & .1311 \\
\hline NPP\&E & .300 & .278 & .259 & .241 & .201 \\
\hline$N P P \& E(S t d)$. & .0021 & .0233 & .0117 & .0121 & .0009 \\
\hline
\end{tabular}


Looking first at the size proxies, it is evident that the average size of KNWL firms has grown considerably over the sample period. For example, mean assets grew from \$244 million in 2000 to $\$ 607$ million in 2018. As for capital structure, there is a noticeable decrease in the amount of debt in the sample firms' capital structure. The mean total debt to total assets ratio (Debt/Assets) declined from .200 in 2000 to .145 in 2018. Similarly, the mean total debt to total capital ratio (Debt/T. Cap.) dropped from .261 in 2000 to .017 (1.7 percent) in 2018. Similar decreases in ROE and FCF/Assets are also evident. The data shows that KNWL firm's growth opportunities have grown over time as both mean MVCS/BVCS and Tobin's q have increased over the sample period. Mean NPP\&E declined from .300 in 2000 to 201 in 2018, indicating that KNWL firms have significantly less collateral available to pledge on debt than they used to.

CI firms display many, but not all, of the trends exhibited by KNWL firms (see table 3). For example, mean Assets grew substantially over the sample period from \$2.350 million in 2000 to \$8.565 million in 2018.

Table 3. Summary statistics for selected variables for the CI firms

\begin{tabular}{|c|c|c|c|c|c|}
\hline & 2000 & 2004 & 2009 & 2014 & 2018 \\
\hline \multicolumn{6}{|c|}{ Panel A: Firm Size } \\
\hline Assets $(\$ M)$ & 2350 & 3962 & 4654 & 6134 & 8565 \\
\hline Assets (Std.) & .1001 & .0301 & .0278 & .0009 & .0024 \\
\hline Sales $(\$ M)$ & 2717 & 3646 & 4184 & 5337 & 7050 \\
\hline Sales (Std.) & .0011 & .0100 & .0091 & .0012 & .0158 \\
\hline $\operatorname{MVCS}(\$ M)$ & 1755 & 2695 & 3395 & 8961 & 8303 \\
\hline $\operatorname{MVCS}(S t d)$. & .0022 & .0078 & .0114 & .0198 & .0177 \\
\hline \multicolumn{6}{|c|}{ Panel B: Capital Structure } \\
\hline Debt $(\$ M)$ & 423 & 1242 & 1286 & 1816 & 2458 \\
\hline $\operatorname{Debt}($ Std. $)$ & .0050 & .0116 & .0033 & .0010 & .0145 \\
\hline Debt/Assets & .211 & .214 & .220 & .248 & .218 \\
\hline Debt/Assets (Std.) & .0051 & .0066 & .0030 & .0012 & .0041 \\
\hline Debt/T. Cap. & .301 & .322 & .311 & .364 & .325 \\
\hline Debt/T. Cap. (Std.) & .0030 & .0031 & .0027 & .0029 & .0019 \\
\hline \multicolumn{6}{|c|}{ Panel C: Profitability, Growth, etc. } \\
\hline ROA & .055 & .058 & .059 & .051 & .038 \\
\hline$R O A(S t d)$. & .0033 & .0041 & .0056 & .0048 & 0.006 \\
\hline ROE & .112 & .115 & .142 & .114 & .079 \\
\hline$R O E(S t d)$. & .0007 & .0011 & .0104 & .0066 & .0001 \\
\hline FCF/Assets & .155 & .149 & .154 & .148 & .139 \\
\hline FCF/Assets (Std.) & .0122 & .0110 & .0121 & .0028 & .0067 \\
\hline MVCS/BVCS & 2.06 & 2.25 & 2.43 & 3.01 & 2.72 \\
\hline$M V C S / B V C S$ (Std.) & .1421 & .1569 & .1625 & .1676 & .1500 \\
\hline Tobin's q & 1.75 & 1.77 & 2.01 & 2.11 & 2.02 \\
\hline Tobin's q (Std.) & .1301 & .1300 & .1488 & .1366 & .1377 \\
\hline NPP\&E & .351 & .355 & .367 & .350 & .329 \\
\hline$N P P \& E(S t d)$. & .0012 & .0173 & .0114 & .0029 & .0012 \\
\hline
\end{tabular}

Also, comparing mean Assets figures, it is evident that the average CI firm is approximately ten times larger than the average KNWL firms. The mean profitability of the CI firms has also declined over the sample period. For example, mean ROA declined form .055 (5.5 percent) in 2000 to .038 in 2018. Other profitability measures exhibit a similar 
trend. Growth opportunities for CI firms have also increased as indicated by the increase in MVCS/BVCS from 2.06 in 2000 to 2.72 in 2018. Over the years under investigation, a tender decline in collateral availability (NPP\&E) is also revealed.

The one trend that is different for CI firms relates to their capital structures. Examining the Debt/Assets ratio, the noticeable decrease in the amount of debt in KNWL firms' capital structures is not evident for CI firms. In fact, there is no discernible trend in the capital structure of CI firms. Moreover, the CI firm has, on average, more debt in its capital structure in each sample year than the average KNWL firm ( 8 percent to 10 percent more over the last decade).

Next objective is to test for the relationship, if any, between firm profitability and capital structure and to see if this relationship has changed over time. This will be accomplished with a regression analysis in which the firm's Debt/Assets ratio is used as the dependent variable. This study goes on with regression analysis for each sample year. The control variables pertain to company size, collateral, growth and risk. Independent variables are ROA and Average ROA (Avg. ROA). While ROA measures current profitability, average annual ROA ( $t$ to year $t-4$ ) provides indications of long-term viability. In table 4, the results of the regression for KNWL firms are presented.

Table 4. Regression analysis of capital structure for KNWL firms

\begin{tabular}{cccccc}
\hline & 2000 & 2004 & 2009 & 2014 & 2018 \\
\hline \multirow{2}{*}{ Intercept (t value) } & $.146 \mathrm{c}$ & $.185 \mathrm{c}$ & $.143 \mathrm{c}$ & $.101 \mathrm{c}$ & $.071 \mathrm{c}$ \\
& $(6.42)$ & $(8.62)$ & $(12.8)$ & $(12.1)$ & $(12.6)$ \\
Assets $\left(10^{4}\right)$ & $.136 \mathrm{c}$ & $.062 \mathrm{c}$ & $.035 \mathrm{c}$ & $.034 \mathrm{c}$ & $.029 \mathrm{c}$ \\
& $(3.24)$ & $(2.67)$ & $(4.12)$ & $(3.65)$ & $(3.51)$ \\
NPP\&E & $.176 \mathrm{c}$ & $.215 \mathrm{c}$ & $.228 \mathrm{c}$ & $.261 \mathrm{c}$ & $.272 \mathrm{c}$ \\
& $(3.02)$ & $(4.28)$ & $(7.12)$ & $(11.6)$ & $(14.3)$ \\
Tobin's q & $-.006 \mathrm{~b}$ & $-.015 \mathrm{c}$ & $-.016 \mathrm{c}$ & $-.002 \mathrm{c}$ & $-.001 \mathrm{c}$ \\
& $(-2.12)$ & $(-3.95)$ & $(-6.45)$ & $(-5.88)$ & $(-3.01)$ \\
ROA & -.048 & -.011 & $.164 \mathrm{c}$ & -.018 & .010 \\
& $(-.051)$ & $(-.016)$ & $(2.85)$ & $(-1.01)$ & $(0.52)$ \\
Avg. ROA & -.132 & $-.231 \mathrm{a}$ & $-.289 \mathrm{c}$ & -.011 & $-.042 \mathrm{a}$ \\
& $(-1.07)$ & $(-1.58)$ & $(-3.11)$ & $(-0.28)$ & $(-1.33)$ \\
Std. ROA & $-.148 \mathrm{a}$ & -.121 & $-.167 \mathrm{c}$ & -.003 & $-.043 \mathrm{~b}$ \\
& $(-1.55)$ & $(-1.24)$ & $(-3.27)$ & $(-0.11)$ & $(-1.99)$ \\
Adj. $\mathrm{R}^{2}$ & .16 & .18 & .27 & .22 & .20 \\
F value & $6.12 \mathrm{c}$ & $11.5 \mathrm{c}$ & $35.1 \mathrm{c}$ & $41.3 \mathrm{c}$ & $49.8 \mathrm{c}$ \\
\hline
\end{tabular}

$\mathrm{a}=$ significant at the $10 \%$ level

$\mathrm{b}=$ significant at the $5 \%$ level

$\mathrm{c}=$ significant at the $1 \%$ level

Regressions shows significant correlation between firm size (Assets) and the amount of debt in the capital structure of education companies. For each sample year, "Asset" coefficient is positive and significant at the 1\% level. Collateral availability is also shown to be a significant determinant of capital structure. The coefficients of NPP\&E are all positive and significant at the $1 \%$ level. Tobin's q ratio remains statistically significant at the $5 \%$ level or better, and negative in all regression. These results indicate that companies with high growth opportunities tend to use less debt than low growth companies. Analysis shows that corporate risk profile, indicated by the coefficient of Std. ROA, is significant factor in determining capital structure composition. Coefficients of Std. ROA are all negative and 3 are statistically significant at the 10 percent significance level or better. These results indicate that company with high risk profile tend to use less debt than company with a lower risk profile. The analysis shows a 
poor relationship between profitability and capital structure. With reference to ROA, only one coefficient is significant and positive. Coefficients of Average ROA are negative in all regression but only one is statistically significant at the five percent significance level or better. In short, results of analysis point out a poor or nonexistent relationship between firm profitability and the amount of debt in KNWL firms' capital structures. This study examined other control and independent variables (Sales and MVCS as size proxies) in the regressions analysis but none of these proved useful in improving capital structure proxy.

Table 5 contains the results of a similar regression analysis performed on CI firms. The coefficients of the four control variables in the CI regression are like those of the corresponding variables in the KNWL regression. Four of the coefficients of Assets are positive and statistically significant at the five percent significance level or better. Also, the coefficients of NPP\&E are all positive, four of which are statistically significant at the 5\% percent significance level or better. Tobin's q ratio remains statistically significant at the $1 \%$ level and negative in all regression. Coefficients of Standard ROA are all negative and 4 are statistically significant at the $1 \%$ significance level. This result is more marked than in KNWL firms. In brief, for the two groups of sample firms (CI and KNWL) regressions shows the strong direct relationship between size and collateral and the amount of debt in capital structures while for growth opportunities and firm risk, relationship is inverse. The results revealed that there's no significant relationship between capital structure and profitability for KNWL firms, while showed strong inverse relationship for CI firms. For CI firms, 4 of the coefficients of ROA are negative and statistically significant at the $1 \%$ significance level. Coefficients of Average ROA are all negative and 3 are statistically significant at the $1 \%$ significance level. These results indicate that the amount of debt in CI firms' capital structures is inversely related with current and long-term profitability ratios.

Table 5. Regression analysis of capital structure for CI firms

\begin{tabular}{cccccc}
\hline & 2000 & 2004 & 2009 & 2014 & 2018 \\
\hline \multirow{2}{*}{ Intercept (t value) } & $.243 \mathrm{c}$ & $.288 \mathrm{c}$ & $.278 \mathrm{c}$ & $.299 \mathrm{c}$ & $.288 \mathrm{c}$ \\
& $(11.1)$ & $(15.4)$ & $(16.1)$ & $(22.1)$ & $(19.8)$ \\
Assets $\left(10^{4}\right)$ & -.009 & $.010 \mathrm{c}$ & $.244 \mathrm{c}$ & $.298 \mathrm{c}$ & $.270 \mathrm{c}$ \\
& $(-1.04)$ & $(2.85)$ & $(2.44)$ & $(2.21)$ & $(2.99)$ \\
NPP\&E & $.119 \mathrm{c}$ & .033 & $.054 \mathrm{~b}$ & $.080 \mathrm{c}$ & $.105 \mathrm{c}$ \\
& $(2.99)$ & $(1.12)$ & $(2.01)$ & $(3.88)$ & $(4.99)$ \\
Tobin's q & $-.011 \mathrm{c}$ & $-.016 \mathrm{c}$ & $-.015 \mathrm{c}$ & $-.010 \mathrm{c}$ & $-.016 \mathrm{c}$ \\
& $(-2.47)$ & $(-2.32)$ & $(-2.88)$ & $(-3.75)$ & $(-2.22)$ \\
ROA & $-.365 \mathrm{c}$ & $-.745 \mathrm{c}$ & $-.505 \mathrm{c}$ & $-.225 \mathrm{c}$ & .004 \\
& $(-2.55)$ & $(-3.22)$ & $(-2.98)$ & $(-1.88)$ & $(-0.03)$ \\
Avg. ROA & -.241 & -.018 & $-.278 \mathrm{c}$ & $-.551 \mathrm{c}$ & $-.599 \mathrm{c}$ \\
& $(-1.22)$ & $(-0.09)$ & $(-2.19)$ & $(-4.21)$ & $(-4.88)$ \\
Std. ROA & $-.545 \mathrm{c}$ & $-.659 \mathrm{c}$ & -.041 & $-.299 \mathrm{c}$ & $-.481 \mathrm{c}$ \\
& $(-2.37)$ & $(-3.88)$ & $(-0.21)$ & $(-2.28)$ & $(-5.01)$ \\
Adj. $\mathrm{R}^{2}$ & .18 & .21 & .20 & .18 & .15 \\
F value & $18.6 \mathrm{c}$ & $22.6 \mathrm{c}$ & $28.9 \mathrm{c}$ & $30.1 \mathrm{c}$ & $34.9 \mathrm{c}$ \\
\hline
\end{tabular}

$\mathrm{a}=$ significant at the $10 \%$ level

$\mathrm{b}=$ significant at the $5 \%$ level

$\mathrm{c}=$ significant at the $1 \%$ level

The findings presented so far clarify that CI firms are more inclined to high debt capital structure than KNWL firms and that profitability is inversely or negatively related in CI firms' capital structures but not in KNWL firms. Regression analysis is used to test the statistical significance of the above findings and was done for each sample year. Regression required two new independent variables. The first is KnwlD, a dummy or binary variable that takes 
on a value of 1 if the sample firm is a KNWL firm and 0 if the sample firm is a CI firm. The coefficient of this dummy variable can indicate if there is a difference in the amount of debt in the capital structures for the two groups of sample companies (KNWL and CI). The second is ROAKnwlD (ROA multiplied by KnwlD), a dummy or binary variable that allows us to test whether indeed there is a difference between firm profitability and capital structure for the two groups of sample companies (KNWL and CI).

Table 6 shows the results of regression analysis. The coefficients of Assets, NPP\&E, Tobin's q, Std. ROA, ROA, and Avg. ROA are like those previously reported. The coefficient of KnwlD is negative and significant at the $1 \%$ level in all regressions. This indicates that, on average, KNWL firms use less debt in their capital structures than CI firms.

In relation to all control variables, the coefficients show that over the last ten years KNWL companies have averaged $14 \%-16 \%$ less debt in their capital structures than CI companies.

Table 6. Regression analysis of capital structure for CI and KNWL firms

\begin{tabular}{cccccc}
\hline & 2000 & 2004 & 2009 & 2014 & 2018 \\
\hline \multirow{2}{*}{ Intercept $(\mathrm{t}$ value $)$} & $.212 \mathrm{c}$ & $.242 \mathrm{c}$ & $.226 \mathrm{c}$ & $.215 \mathrm{c}$ & $.179 \mathrm{c}$ \\
& $(12.9)$ & $(12.8)$ & $(19.1)$ & $(20.1)$ & $(19.7)$ \\
Assets $\left(10^{4}\right)$ & .001 & $.014 \mathrm{c}$ & $.009 \mathrm{c}$ & $.004 \mathrm{c}$ & $.002 \mathrm{c}$ \\
& $(0.08)$ & $(2.72)$ & $(2.98)$ & $(2.65)$ & $(3.88)$ \\
NPP\&E & $.121 \mathrm{c}$ & $.116 \mathrm{c}$ & $.125 \mathrm{c}$ & $.142 \mathrm{c}$ & $.199 \mathrm{c}$ \\
& $(4.02)$ & $(3.99)$ & $(7.79)$ & $(12.9)$ & $(15.1)$ \\
Tobin's q & $-.008 \mathrm{c}$ & $-.012 \mathrm{c}$ & $-.013 \mathrm{c}$ & $-.002 \mathrm{c}$ & $-.001 \mathrm{c}$ \\
& $(-3.01)$ & $(-4.26)$ & $(-7.81)$ & $(-7.65)$ & $(-3.12)$ \\
KnwlD & $-.044 \mathrm{c}$ & $-.081 \mathrm{c}$ & $-.091 \mathrm{c}$ & $-.111 \mathrm{c}$ & $-.088 \mathrm{c}$ \\
& $(-2.96)$ & $(-3.01)$ & $(-8.12)$ & $(-15.99)$ & $(-12.15)$ \\
ROA & $-.456 \mathrm{c}$ & $-.698 \mathrm{c}$ & $-.565 \mathrm{c}$ & $-.611 \mathrm{c}$ & $-.371 \mathrm{c}$ \\
& $(-3.12)$ & $(-3.78)$ & $(-4.12)$ & $(-6.10)$ & $(-3.90)$ \\
ROAKnwlD & $.418 \mathrm{c}$ & $.512 \mathrm{c}$ & $.712 \mathrm{c}$ & $.685 \mathrm{c}$ & $.429 \mathrm{c}$ \\
& $(2.86)$ & $(3.12)$ & $(6.88)$ & $(7.12)$ & $(2.95)$ \\
Avg. ROA & $-.199 \mathrm{~b}$ & $-.209 \mathrm{~b}$ & $-.212 \mathrm{c}$ & $-.091 \mathrm{~b}$ & $-.111 \mathrm{c}$ \\
& $(-1.88)$ & $(-1.92)$ & $(-4.01)$ & $(-1.98)$ & $(-3.55)$ \\
Std. ROA & $-.197 \mathrm{c}$ & $-.141 \mathrm{~b}$ & $-.161 \mathrm{c}$ & $-.048 \mathrm{c}$ & $-.061 \mathrm{c}$ \\
Adj. R & $(-2.66)$ & $(-2.12)$ & $(-3.35)$ & $(-1.99)$ & $(-2.98)$ \\
F value & .14 & .16 & .21 & .19 & .17 \\
& $15.1 \mathrm{c}$ & $19.8 \mathrm{c}$ & $38.9 \mathrm{c}$ & $64.1 \mathrm{c}$ & $63.9 \mathrm{c}$ \\
\hline
\end{tabular}

$\mathrm{a}=$ significant at the $10 \%$ level

$\mathrm{b}=$ significant at the $5 \%$ level

$\mathrm{c}=$ significant at the $1 \%$ level

The coefficients of ROAKnwlD are all positive and statistically significant at the $1 \%$ significance level. This indicates that there is a statistically significant difference in the relationship between profitability and capital structure for the two groups of sample firms (CI and KNWL). The coefficient of ROA shows this relationship for CI firms and throughout the sampled years indicates a statistically significant inverse correlation between profitability and capital structure. The sum of the coefficients of ROA and ROAKnwlD shows the relationship for KNWL firms. For example, for 2018 the sum of the coefficients is .058 (-.371 +.429). As .058 is not statistically significant relevant when compared to conventional levels $(\mathrm{t}=0.63)$, the absence of a relationship between profitability and capital structure for KNWL companies is clear. The same is true for all other sample years. In brief, these regressions 
revealed that there's no significant relationship between capital structure and profitability for KNWL firms, while showed strong inverse relationship for CI firms.

\section{Concluding Remarks}

This study seeks to understand financing choices by for-profit education companies listed on NASDAQ and NYSE. Despite the existence of many empirical studies investigating the impact of firms' characteristics on financial policies, quite surprisingly there is no research explicitly investigating (empirically or theoretically) financial policies of for-profit education firms. With reference to companies listed on the NYSE and NASDAQ stock markets, this study shows that capital-intensive firms belonging to the CI group on average have higher debt ratios than education companies belonging to the KNWL group. Furthermore, debt ratios for the KNWL sample firms went down significantly, while for firms in the CI group they remained relatively stable during 2000-2018. Also, while there is a strong inverse relationship between profitability and the amount of debt in the capital structure of CI firms, no such relationship was found between these two variables for the KNWL firms. Therefore, these results confirm first research hypothesis (H1) and reject the second (H2).

Regression analysis output allow us to affirm that the high endowment of intangible capital generates large growth opportunities and in order to avoid the underinvestment and the asset substitution problem, knowledge-based companies or intangible asset intensive companies prefer equity to debt. These results are consistent with previous studies by Myers (1977), Bah and Dumontier (2001), and Parthiban et al. (2008). Intangible investments such as $\mathrm{R} \& \mathrm{D}$, branding, patent, trademark, and technology development are specific assets and non-redeployable with lower guarantee value for the creditors. As a result and in accordance with the transaction cost theory (Harris and Raviv, 1991; Bah and Dumontier, 2001; Benmelech, 2009; Hall and Lerner, 2010; Qiu and La, 2010; Wang and Tornhill, 2010), this work highlights that KNWL firms prefer equity to debt. Results on collateral availability and risk profile are consistent with previous studies related adverse selection and moral hazard (Bradley et al., 1984; Aghion et al., 2004; Singh and Faircloth, 2005).

With reference to the relationship between profitability and the amount of debt in the firm's capital structure, this work highlights the validity of Myers and Majluf's theory (1984) for CI companies but not for KNWL firms. For KNWL companies the problem of free cash flow predominates and therefore Jensen's theory (1986) justifies the absence of inverse relationship. Firm's capital structure choice is a complicated topic, which theory alone cannot always explain.

This work shows decreasing weight of debt component in the education company's capital structure, the absence of an inverse relationship between debt and profitability, and the strong direct relationship between collateral and the amount of debt in capital structure. These results lead us to believe that capital structure of education firm is dictated by high endowment of intangibles assets and, consequently by information asymmetries between firms and external financial partners. Findings of this work lead to some implications of potential interest. Banks should adopt rating models more sensitive to soft information. A new "rating philosophy" is suggested that does not neglect the relationship with the clientele and who is able to intercept the value expressed by intangible endowment of firm (Quintiliani, 2017). Furthermore, policymakers should stimulate development of the private equity market. A financing tool that is considered adequate for the development needs of education companies increasingly attentive to the provision of high-tech services as shown by development of e-learning platforms in the last ten years. This reflection is even more sensible in a historical moment that sees global economy affected by Covid-19.

It should be emphasized that the present work limits its field of investigation to a few variables without fully addressing other elements which may condition education stocks. It is expected that subsequent studies can use larger samples of education companies listed on different stock markets.

This study represents a benchmark for future empirical research related to the internal factors specific to the companies operating in the for-profit education industry.

\section{References}

Abramovitz, M., \& David, P. A. (2000). American Macroeconomic Growth in the Era of Knowledge-Based Progress: The Long-Run Perspective. In S. L. Engerman \& R. E. Gallman (Eds.), The Cambridge Economic History of the United States (pp. 1-92). New York, NY: Cambridge University Press. https://doi.org/10.1017/CHOL9780521553087.002

Aghion, P., Bond, S., Klemm, A., \& Marinescu, I. (2004). Technology and financial structure: Are innovative firms different? Journal of the European Economic Association, 2(2-3), 277-288. https://doi.org/10.1162/154247604323067989 
Ang, J., Cole, R., \& Lin, J. (2000). Agency costs and ownership structure. Journal of Finance, 55(1), 81-106. https://doi.org/10.1111/0022-1082.00201

Arellano, M., \& Bover, O. (1995). Another look at the instrumental variable estimation of error-components models. Journal of Econometrics, 68(1), 29-51. https://doi.org/10.1016/0304-4076(94)01642-D

Bah, R. \&, Dumontier, P. (2001). R\&D Intensity and Corporate Financial Policy: Some International Evidence. Journal of Business Finance \& Accounting, 28(5-6), 671-692. https://doi.org/10.1111/1468-5957.00389

Baker, H. K., Saadi, S., Dutta, S., \& Gandhi, D. (2007). The perception of dividends by Canadian managers: new survey evidence. International Journal of Managerial Finance, 3(1), 70-91. https://doi.org/10.1108/17439130710721662

Baker, M., \& Wurgler, J. (2002). Market Timing and Capital Structure. The Journal of Finance, 57(1), 1-32. https://doi.org/10.1111/1540-6261.00414

Banerjee, S., Heshmati, A. \& Wihlborg, C. (2004). The dynamics of capital structure. Research in Banking and Finance, 4, 275-297. https://doi.org/10.1016/S1567-7915(04)04011-X

Benmelech, E. (2009). Asset Salability and Debt Maturity: Evidence from Nineteenth-Century American Railroads. The Review of Financial Studies, 22(4), 1545-1584. https://doi.org/10.1093/rfs/hhn036

Bennedsen, M., Nielsen, K. M., Perez-Gonzalez, F., \& Wolfenzon, D. (2007). Inside the Family Firm: The Role of Families in Succession Decisions and Performance. The Quarterly Journal of Economics, 122(2), 647-691. https://doi.org/10.1162/qjec.122.2.647

Berger, P. G., Ofek, E., \& Yermack, D. L. (1997). Managerial Entrenchment and Capital Structure Decisions. The Journal of Finance, 52(4), 1411-1438. https://doi.org/10.1111/j.1540-6261.1997.tb01115.x

Blundell, R., \& Bond, S. (1998). Initial conditions and moment restrictions in dynamic panel data models. Journal of Econometrics, 87(1), 115-143. https://doi.org/10.1016/S0304-4076(98)00009-8

Bradley, M., Jarrell, G. A., \& Kim, E. H. (1984). On the Existence of an Optimal Capital Structure: Theory and Evidence. The Journal of Finance, 39(3), 857-878. https://doi.org/10.2307/2327950

Brown, J. R., Fazzari, S. M., \& Petersen, B. C. (2009). Financing Innovation and Growth: Cash Flow, External Equity, and the 1990s R\&D Boom. The Journal of Finance, 64(1), 151-185. https://doi.org/10.1111/j.1540-6261.2008.01431.x

Canarella, G., \& Miller, S. M. (2019). Determinants of Optimal Capital Structure and Speed of Adjustment: Evidence From the U.S. ICT Sector. https://doi.org/10.2139/ssrn.3354975

Carpenter, R. E., \& Petersen, B. C. (2002). Capital Market Imperfections, High-tech Investment, and New Equity Financing. The Economic Journal, 112(477), F54-F72.

Chung, K. H., \& Pruitt, S. W. (1994). A Simple Approximation of Tobin's q. Financial Management, 23(3), 70-74. https://doi.org/10.2307/3665623

Dang, C., Li, Z. F., \& Yang, C. (2018). Measuring firm size in empirical corporate finance. Journal of Banking \& Finance, 86, 159-176. https://doi.org/10.1016/j.jbankfin.2017.09.006

DeAngelo, H., \& Masulis R. W. (1980). Optimal capital structure under corporate and personal taxation. Journal of Financial Economics, 8(1), 3-29. https://doi.org/10.1016/0304-405X(80)90019-7

Fama, E. F., \& French, K. R. (2001). Disappearing dividends: changing firm characteristics or lower propensity to pay? Journal of Financial Economics, 60, 3-43. https://doi.org/10.1016/S0304-405X(01)00038-1

Faulkender, M., \& Petersen, M. A. (2006). Does the source of capital affect capital structure? Review of financial studies, 19(1), 45-79. https://doi.org/10.1093/rfs/hhj003

Frank, M. Z., \& Goyal, V. K. (2009). Capital structure decisions: Which factors are reliably important? Financial Management, 38(1), 1-37. https://doi.org/10.1111/j.1755-053X.2009.01026.x

Friend, I., \& Lang, L. H. P. (1988). An Empirical Test of the Impact of Managerial Self-Interest on Corporate Capital Structure. The Journal of Finance, 43(2), 271-281. https://doi.org/10.2307/2328459

Galor, O., \& Moav, O. (2004). From Physical to Human Capital Accumulation: Inequality and the Process of Development. Review of Economic Studies, 71, 1001-1026. https://doi.org/10.1111/0034-6527.00312

Giroud, X., Mueller, H. M., Stomper, A., \& Westerkamp, A. (2012). Snow and Leverage. The Review of Financial 
Studies, 25(3), 680-710. https://doi.org/10.1093/rfs/hhr113

Guedes, J., \& Opler, T. (1996). The Determinants of the Maturity of Corporate Debt Issues. The Journal of Finance, 51(5), 1809-1833. https://doi.org/10.2307/2329539

Hall, B. H., \& Lerner, J. (2010). Chapter 14 - The Financing of R\&D and Innovation. In B. H. Hall \& N. Rosenberg (Eds.), Handbook of The Economics of Innovation, Vol. 1 (pp. 609-639). Amsterdam, NL: Elsevier. https://doi.org/10.1016/S0169-7218(10)01014-2

Harris, M., \& Raviv, A. (1991). The Theory of Capital Structure. The Journal of Finance, 46(1), 297-355. https://doi.org/10.1111/j.1540-6261.1991.tb03753.x

Hogan, T., \& Hutson, E. (2004). Capital Structure in New Technology-Based Firms: Financing in the Irish Software Sector. https://doi.org/10.2139/ssrn.498283

Jensen, G. R., Solberg, D. P., \& Zorn, T. S. (1992). Simultaneous Determination of Insider Ownership, Debt and Dividend Policies. The Journal of Financial and Quantitative Analysis, 27(2), 247-263. https://doi.org/10.2307/2331370

Jensen, M. C. (1986). Agency Cost of Free Cash Flow, Corporate Finance, and Takeovers. The American Economic Review, 76(2), 323-329.

Jensen, M. C., \& Meckling, W. H. (1976). Theory of the Firm: Managerial behavior, agency costs and ownership structure. Journal of Financial Economics, 3(4), 305-360. https://doi.org/10.1016/0304-405X(76)90026-X

Kim, C-S., Mauer, D. C., \& Sherman, A. E. (1998). The Determinants of Corporate Liquidity: Theory and Evidence. The Journal of Financial and Quantitative Analysis, 33(3), 333-359. https://doi.org/10.2307/2331099

Kopecky, K. J., Li, Z. F., Sugrue, T. F., \& Tucker, A. L. (2018). Revisiting M\&M with Taxes: An Alternative Equilibrating Process. International Journal of Financial Studies 6(1), 1-12. https://doi.org/10.3390/ijfs6010010

Kraus, A., \& Litzenberger, R. H. (1973). A State-Preference Model of Optimal Financial Leverage. The Journal of Finance, 28(4), 911-922. https://doi.org/10.2307/2978343

Laeven, L., \& Ross, L. (2009). Bank governance, regulation and risk taking. Journal of Financial Economics, 93(2), 259-275. https://doi.org/10.1016/j.jfineco.2008.09.003

Leventhal, M., \& Tang, I. (2013). A Sector of Interest: Institutions \& Schools. Retrieved from https://equityforeducation.wordpress.com/author/equityforeducation/

Li, F. (2016). Endogeneity in CEO power: A survey and experiment. Investment Analysts Journal, 45(3), 149-162. https://doi.org/10.1080/10293523.2016.1151985

Lucas, D. J., \& McDonald, R. L. (1990). Equity Issues and Stock Price Dynamics. The Journal of Finance, 45(4), 1019-1043. https://doi.org/10.2307/2328713

MacKie-Mason, J. K. (1990). Do Taxes Affect Corporate Financing Decisions? The Journal of Finance, 45(5), 1471-1493. https://doi.org/10.2307/2328746

Modigliani, F., \& Miller, M. H. (1958). The Cost of Capital, Corporation Finance and the Theory of Investment. The American Economic Review, 48(3), 261-297.

Myers, S. C. (1977). Determinants of corporate borrowing. Journal of Financial Economics, 5(2), pp.147-175. https://doi.org/10.1016/0304-405X(77)90015-0

Myers, S. C. (1984). The Capital Structure Puzzle. The Journal of Finance, 39(3), 575-592. https://doi.org/10.1111/j.1540-6261.1984.tb03646.x

Myers, S. C., \& Majluf, N. S. (1984). Corporate financing and investment decisions when firms have information that investors do not have. Journal of Financial Economics, 13(2), 187-221. https://doi.org/10.3386/w1396

Nasdaq.com (2018). 5 Top-Ranked Education Stocks to Buy for 2019. Retrieved from https://www.nasdaq.com/articles/5-top-ranked-education-stocks-buy-2019-2018-12-21

O'Brien J. P. (2003). The Capital Structure Implications of Pursuing a Strategy of Innovation. Strategic Management Journal, 24(5), 415-431. https://doi.org/10.1002/smj.308

OECD (1999). Oecd Science, Technology and Industry Scoreboard 1999: Benchmarking Knowledge-Based Economies. Paris, FR: Organization for Economic. https://doi.org/10.1787/sti_scoreboard-1999-en 
Opler, T., Pinkowitz, L., Stulz, R., \& Williamson, R. (1999). The determinants and implications of corporate cash holdings. Journal of Financial Economics, 52(1), 3-46. https://doi.org/10.1016/S0304-405X(99)00003-3

Parthiban, D., O’Brien, J. P., \& Yoshikawa, T. (2008). The Implications of Debt Heterogeneity for R\&D Investment and Firm Performance. The Academy of Management Journal, 51(1), 165-181. https://doi.org/10.2307/20159500

Qiu, M., \& La, B. (2010). Firm Characteristics as Determinants of Capital Structures in Australia. International Journal of the Economics of Business, 17(3), 277-287. https://doi.org/10.1080/13571516.2010.513810

Quintiliani, A. (2017). Bank-Firm relationships and Intangibles: Adverse Selection Approach for the MAS innovation of Chief Financial Officer. European Journal of Economics, Finance and Administrative Sciences, 96, 25-37.

Rajan, R. G., \& Zingales, L. (1995). What Do We Know about Capital Structure? Some Evidence from International Data. The Journal of Finance, 50(5), 1421-1460. https://doi.org/10.1111/j.1540-6261.1995.tb05184.x

Rampini, A. A., \& Viswanathan, S. (2013). Collateral and capital structure. Journal of Financial Economics, 109(2), 466-492. https://doi.org/10.1016/j.jfineco.2013.03.002

Robb, A. M., \& Robinson, D.T. (2014). The Capital Structure Decisions of New Firms. The Review of Financial Studies, 27(1), 153-179. https://doi.org/10.1093/rfs/hhs072

Ross, S. A. (1977). The Determination of Financial Structure: The Incentive-Signalling Approach. The Bell Journal of Economics, 8(1), 23-40. https://doi.org/10.2307/3003485

Scott, J. H. (1977). Bankruptcy, Secured Debt and Optimal Capital Structure. The Journal of Finance, 32(1), 1-19. https://doi.org/10.2307/2326898

Shyam-Sunder, L., \& Myers, S. C. (1994). Testing static trade-off against pecking order models of capital structure. Journal of Financial Economics, 51(2), 219-244. https://doi.org/10.1016/S0304-405X(98)00051-8

Singh, M., \& Faircloth, S. (2005). The impact of corporate debt on long term investment and firm performance. Applied Economics, 37(8), 875-883. https://doi.org/10.1080/00036840500076762

Titman, S., \& Wessels, R. (1988). The Determinants of Capital Structure Choice. The Journal of Finance, 43(1), 1-19. https://doi.org/10.1111/j.1540-6261.1988.tb02585.x

Wang, T., \& Thornhill, S. (2010). R\&D investment and financing choices: A comprehensive perspective. Research Policy, 39(9), 1148-1159. https://doi.org/10.1016/j.respol.2010.07.004 